\title{
Conceptions of mountain formation, folding, fault and the continental drift in geography textbooks between the decades of 1930 to 1960
}

\author{
Danilo M. da Costa, Edson R. de Souza \\ Institute of Geosciences, Graduate Program of Teaching and History of Earth Sciences. University of Campinas (Campinas State University), Zeferino Vaz University \\ Campus, Rua Carlos Gomes, 250, Barão Geraldo, 13083-855, Campinas, SP. \\ E-MAlL: GE0.MOSCA@HotMAlL.com, FISEDSONSON@GMAl.com
}

Abstract: The conceptions about the origins of mountains, faults, folds or relief are very different if we compare didactic books of Geography published before and after the elaboration of Plates Tectonics theory. In this article, it was analyzed didactic books from first grade education, which is currently equivalent to the $6^{\text {th }}$ grade of Elementary School 2, published between 1933 until 1961. Obviously, by that time, Plate tectonics theory had not yet been elaborated. However, the academic world was already familiar with the Continental Drift theory, an innovative proposal elaborated at the beginning of the 20th century by German scientist Alfred Wegener [1880-1930]. According to Wegener, the continents were together millions of years ago, forming a single great mass, called by him of "Pangea". Considering that the books analyzed were published between 1933 and 1961, such works could be expected to contemplate and explain the continental drift theory. However, it was not what it was observed. In addition, the formation of mountains, folds, faults or relief had very different conceptions of what today's students learn.
Manuscript:

Received: Quadrennial Conference of the International Geoscience Education Organization

Accepted: 14/01/2018

Citation: Costa D.M., Souza E.R. 2018. Conceptions of mountain formation, folding, fault and the continental drift in geography textbooks between the decades of 1930 to 1960. Terræ Didatica, 14(4):349-354. URL: http://www.ige.unicamp.br/terraedidatica/.

Keywords: Plate Tectonics, continental drift, mountain formation, Geography textbooks.

Subject line: Geosciences and Natural Sciences for Basic Education

\section{Introduction}

The analysis of old textbooks allows us to glimpse what contents were taught at a given time. It is also possible, to make comparisons between scientific conceptions in different periods, establishing important correlations that allow us, among other things, to measure how certain concepts and / or theories have been validated or not by the scientific community

In this article, we seek to identify how the old Geography textbooks, especially the books published between the 1930s and 1960s for the $1^{\text {st }}$ grade of the old junior high school course, which corresponds today to the $6^{\text {th }}$ year of Elementary School 2, addressed themes related to internal dynamics from the Earth. The topics analyzed were the formation of mountains, folding and the theory of Continental drift, considering that the Plate tectonics theory had not yet been elaborated.

In order to carry out this research, we acquired old Geography textbooks in "sebos"(thrift shops) in the city of Campinas or online, purchased at two main websites: Estante Virtual (www.estantevirtual. com.br) and Mercado Livre (www.mercadolivre. com.br).

The libraries of the Institute of Geosciences (IG) and of the Faculty of Education (Faculdade de Educação, FE) of Unicamp were also used, to get access to books not found in thrift shops or online.

This way, it was possible to obtain old works, but well conserved despite the time and with contents that were analyzed according to the purpose of this research.

This article is part of a masters research, still under development, within the Teaching and History of Earth Sciences Program (EHCT), from Universidade Estadual de Campinas (Unicamp) (University of Campinas).

\section{The Earth's Internal Dynamics}

\section{1 - Plate Tectonics and the Continental Drift}

Since its elaboration between 1967 and 1968, plate tectonics theory explains that slow but continuous movements of lithosphere plates are 
responsible for the creation of folds or mountains, which arise mainly at converging boundaries, when one plate "plunges" under another (subduction movement).

When submerged, the older and/ or denser plate plunges under another lighter plate and enters the mantle, merging. This type of movement creates tensions that in the surface, over millions of years, in the boundaries between these plates, will raise the relief, creating folds / mountains or faults. Along with this phenomenon, seismic shocks and volcanism can also occur (Suguio \& Suzuki 2003).

The terrestrial surface is therefore divided into many plates, which move in different directions, moving apart, rubbing or colliding with each other, as shown in Figures 1 and 2.

Plate tectonics used as a basis the hypotheses of Alfred Wegener [18801930], a German scientist who proposed the theory of the Continental Drift in the early $20^{\text {th }}$ century.

Wegener sought, throughout his life, to prove his theory. According to this researcher, the continents made "lateral" movements, and in past geological times, all would be united in a single mass; called "Pangea" (Branco \& Branco 1992), as shown in figure 3.

About 200 million years ago, this supercontinent would have begun to fragment acquiring over time the current positions (Suguio \& Suzuki 2003).

The fitting alignment between Africa and South America, and the discovery of similar rocks and fossils (of families, genres and species) between these two continents, which were once together, were arguments used by the scientist, who managed to find followers of his thought, as Arthur Holmes [1890-1965], one of the most respected international geologists and Alexander Du Toit [1878-1948], professor of geology at the University of South Africa.

This last researcher refined Pangea in two parts: "Laurasia and Gondwana" (Tassinari \& Dias Neto 2009). According to Arthur Holmes himself, for many years, Du Toit was tirelessly gather-

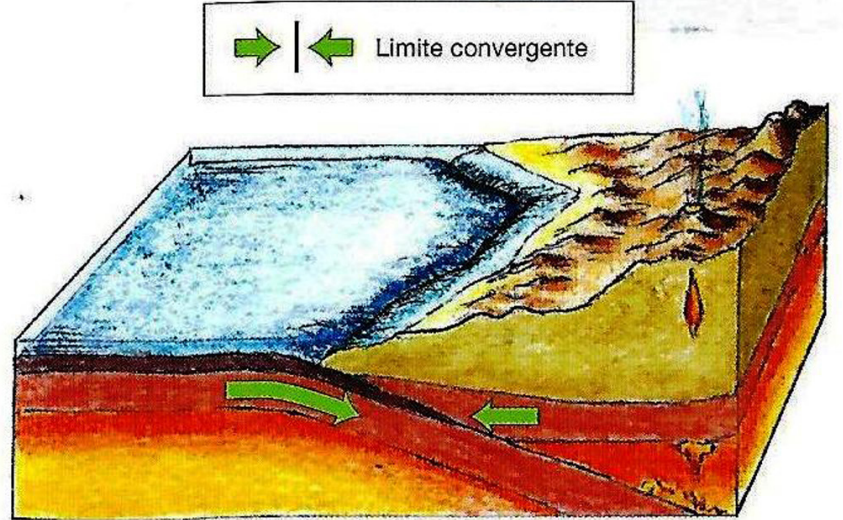

Figure 1. Convergent motion and subduction of the oceanic plate. Source: Ferreira (2013)

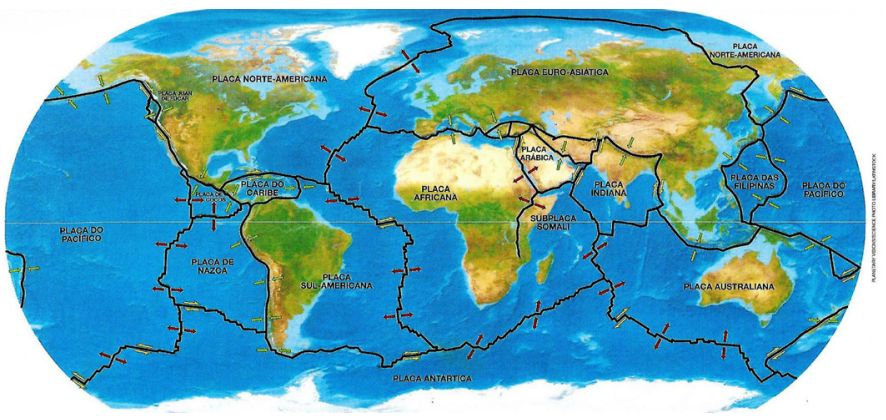

Figure 2. Tectonic Plates. Source: Ferreira (2013)

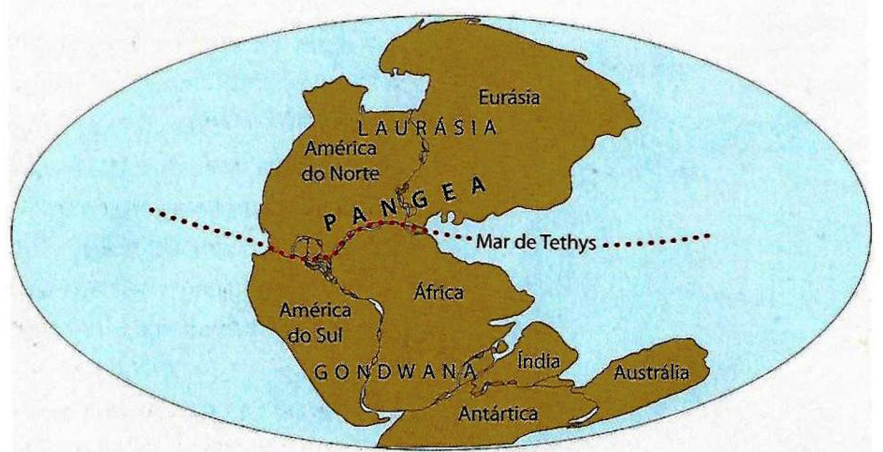

Figure 3. The supercontinent Pangea. Source: Tassinari \& Dias Neto (2009)

ing evidence in support of the Continental Drift (Holmes 1952).

For Holmes (1952), Wegener attributed the drift of the continents to the gravitational pull exerted by the Earth's equatorial protuberance. Wegener, also assumed a general drift towards the west. For him, as the two Americas moved against the resistance of the Pacific bottom, its front part wrinkled, forming a great chain of mountains (Holmes 1952).

Would such mountains be the great modern

\begin{tabular}{c|c|c|c|c|c}
\hline (C) Terrae Didat. & Campinas, SP & v.14 & n.4 & p. 349-354 & out./dez. 2018 \\
\hline
\end{tabular}


folds of America, such as the Andes, for example? Finally, Wegener concludes that in this great displacement to the west, a trail of fragments left behind formed the islands of the Antilles (Holmes 1952).

However, Wegener could never prove to the more skeptical that forces would be able to perform the lateral movement of the continents. "The American society of Petroleum Geologists, for example, ridiculed Wegener, calling him crazy" (Suguio \& Suzuki 2003, page 19).

According to Holmes (1952), as a scientist, Wegener got an important collection of facts and opinions that supported his theory. Some of his evidence is quite logical, but many of his defenses were based on speculation and allegations that sparked a storm of adverse criticism. Such a hypothesis was considered improbable. After all, how huge rock blocks could move?

Therefore, most geologists have proved refractory to admit the possibility of continental drift, since no known natural process seemed to have the most remote possibility of such a movement (Holmes 1952).

Unfortunately, Wegener passed away without being able to prove his ideas, and so the old textbooks of Geography, especially the editions of the 1930s and 1960s, brought little or no information on the Continental Drift. His ideas gradually became obsolete (Branco \&Branco 1992).

The acceptance to the Continental Drift theory came due to deep ocean explorations and the dating of underwater rocks during and after the World War 2 (1940s and 1950s). At that time, the theory of the expansion of the marine floor was formulated. New equipment made it possible to map a gigantic system of mountain ranges in the Atlantic Ocean, called the mid-ocean ridge. It was soon noticed that these sites could represent the rupture produced during the separation of the continents and that new magmatic material was constantly produced and released by fractures and faults, thus creating a new part of the lithosphere, as shown in figure 4, below (Tassinari \& Dias Neto 2009).

However, if the crust grows in the mid-ocean ridge, destruction should take place somewhere else, unless our planet was in continuous expansion. It was then found that the crust is continuously "recycled", being consumed in subduction areas, as mentioned previously. "Therefore, because of the expansion of the ocean floor, the continents would travel fixed on a plate, like passengers on a treadmill" (Tassinari

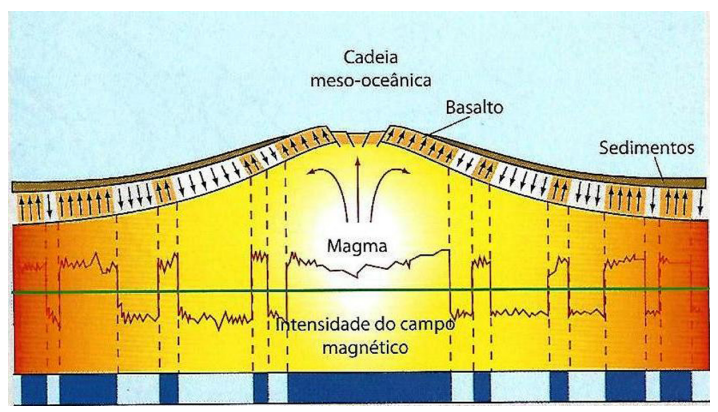

Figure 4. Profile through a mid-ocean ridge. Source: Tassinari \& Dias Neto (2009)

\& Dias Neto 2009, page 85).

This way, the international scientific community realized that Wegener was not wrong in proposing the lateral movement of the continents and "[...] by the conjunction of Continental Drift theory and the expansion of the seafloor, the Plate Tectonics theory was conceived (Suguio \& Suzuki 2003, page 19). Today, nearly a century after his death, the drift of the continents is virtually unopposed, such as its acceptance and presence in textbooks and scientific articles. However, unfortunately, it is mentioned in only one of the five textbooks used in this work.

The creation of mountains, folds, faults and the formation of the earth's relief were also subjects presented in a very different way from what we find today in Geography textbooks. We will look at this part in the analysis and results section below.

\subsection{Analysis and results}

In the following paragraphs, we will describe how some authors conceptualized the formation of mountains, faults or folds on our planet and whether or not they mention the Continental Drift in the didactic texts analyzed. Table 1 , below, shows the five books that were investigated in this article. We remind you that all books refer to the 1 st grade of the old junior high school.

Table 1. Geography Textbooks [1933-1961]

\begin{tabular}{l|l|l}
\hline $\begin{array}{l}\text { Author } \\
\text { (surnames) }\end{array}$ & Title & Year \\
\hline Lima & Geografia Secundária & 1933 \\
\hline Lenz & Geografia & 1942 \\
\hline Gicovate & Geografia Geral & 1944 \\
\hline Lima Filho & Noções de Geografia Geral & 1953 \\
\hline Azevedo & Geografia Geral & 1961 \\
\hline
\end{tabular}


The first book analyzed was "Geografia secundária"(Secondary Geography) by A.G. Lima, whose publication dates from 1933, by Livraria do Globo (Globo's Bookstore).

Lima (1933) describes in his book that to explain the origin of terrestrial relief forms, it is possible to demonstrate mathematically that the Earth had other satellites, which were attracted by the gravity of our planet and "fell" on our surface. Such satellites, as they approached, exerted such a great attraction on this terrestrial surface that they provoked a sort of "tide" in the supposed substances in fusion within the Earth.

According to Lima (1933), these "tides" propelled the earth's crust up and formed the extinct mountainous systems and those that persist today, since they were the last to be created

In addition to these explanations, the author also writes that the surface of the Earth would be diminishing, and with this reduction, there would be a wrinkling of the crust, forming the "folds", for example. There is no mention of the Continental Drift.

Similarly, with Lima's (1933) ideas about wrinkling of the crust, Lenz (1942) describes that as a consequence of the contraction of the globe, the outer crust has crept in many places and the rainwater has gathered in others, thus forming the seas and continents. The author adds that frequent and torrential rains of hot water dissolved the rocks, causing continental relief unevenness and sedimentary soils rose because of the Earth's contraction, forming high mountains of fossiliferous debris (Lenz 1942).

This author adopts a different approach from the others analyzed, because he uses Biblical explanations in his book, having as reference, according to him, the cosmographer P. Godofredo Schrader S.J.

In explaining the creation of planet Earth, Lenz (1942) mixes science and religion, using the sevenday mosaic to justify what ever happened to our planet, which, according to him [...] "after being adorned with plants and animals of various species, man appeared as the king of creation by the will of God (6 mosaic day) “. (page 74).

Even when mixing science and religion, his book clarifies on the back cover that follows the official government programs of his time. We have not yet been able to obtain these old official programs, which helped to understand the curriculum proposed by the government in previous decades. Finally, just as Lima's Book (1933), there is no mention of the Continental Drift.

Following the chronological sequence of the books publications, the next author that we analyzed was Moses Gicovate, whose didactic work dates from 1944.

Gicovate is the only author who does not explain at any time about the formation of mountains. However, despite the lack of this content, we decided to insert this author because he is the only one of the five authors analyzed in this research, which brings in his book the ideas of continental drift from Alfred Wegener.

Gicovate (1944) quotes Alfred Wegener as an "eminent geologist," who issued a "curious hypothesis" (page 66). According to Gicovate (1944), Wegener was deeply impressed with the similarities between the coasts of Brazil and Africa. Thus, the earth's crust once formed an immense and only rocky block, which split and separated (Gicovate 1944).

The author continues to explore Wegener's ideas, explaining, "Each of the blocks of the crust, or each continent, like an iceberg, plunged into the pyrosphere, or rather into the pit, began its journey westward" (Gicovate 1944, page 66). In addition to being separated into blocks, the oceans were created as the continents moved away from each other.

Gicovate (1944) portrays Wegener's ideas with two images. The first shows the similarity between the African and Brazilian coasts, as we can see in Figure 5.

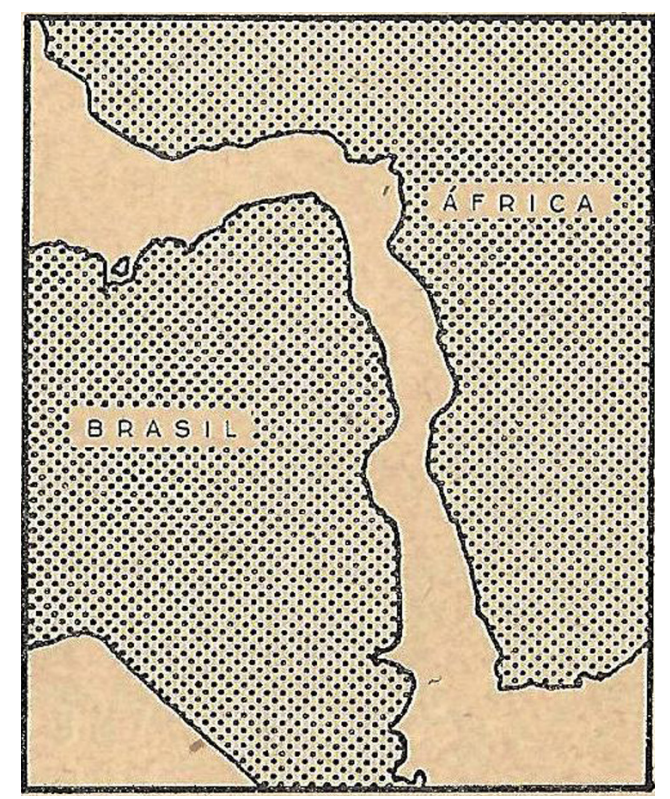

Figure 5. Coincidence between the cut of the coasts of Africa and those of Brazil. Source: Gicovate (1944) 
In Figure 6, Gicovate (1944) first sought to portray the immense united block (Pangea) and later fragmented into parts, giving rise to the present position of the continents.

It is not known why Gicovate (1944) inserted Wegener in his book, since none of other authors did in the same way. Until up to the point of this research, we do not know yet if the continental drift is part of the curriculum suggested by the official government programs of his time. This research should be approached in detail in a master's dissertation in the future. At this moment, we limited ourselves to say that only one of the five books of Geography approaches the theory of continental drift.

Reinforcing what was said earlier; Wegener died in 1930, on an expedition to Greenland and was unable to prove his theory. Therefore, we can infer that it is uncommon to find no reference to this scientist and his ideas in Geography textbooks.

Years later, Lima Filho (1953), in his work entitled "Notions of General Geography", describes that the cooling of the lithosphere, originated its retraction and produced a series of folds, faults or fractures. For the author, at certain points, there were huge spines of mountain ranges. In others, they formed concavities, where the waters, oceans and seas were deposited. Giant folds, such as Himalayas, Alps, Andes and Rocky Mountains, were, according to the author, the result of a "tertiary wrinkling." In the book by Lima Filho (1953), there is also no mention of the Continental Drift theory.

The last book analyzed was from Aroldo de Azevedo, whose publication was acquired in 1961.

Azevedo dominated the textbook market in the 1940's, 50's and 60's. Most of the professors between the 1940's and 1960's preferred teaching from his books.

His first book dates from 1937, before even obtaining his diploma of the superior course in Geography by the University of São Paulo (Vesentini 2008).

In his work, Azevedo (1961) describes that the surface of the planet is far from being equal and uniform.

For him, mountains constitute the greatest juts of the earth's crust, which is still a correct principle. To explain its origin, the author writes about the slow cooling of the Earth that is responsible for the displacements of the crust. The layers could fracture or wrinkle, according to horizontal and vertical pressures in a certain terrain. We also find no mention of continental drift nor of Alfred Wegener.

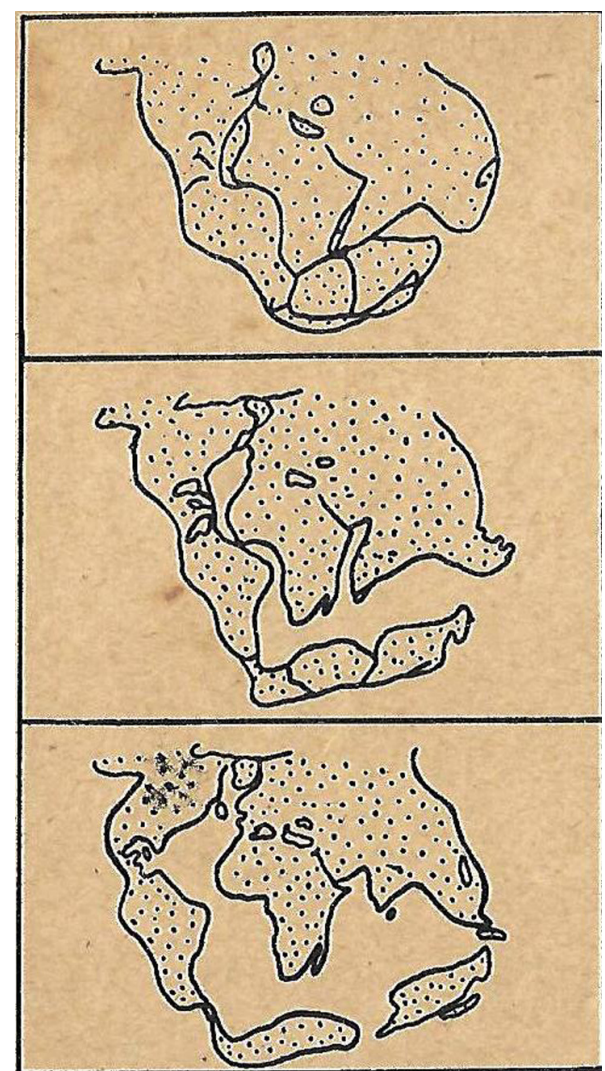

Figure 6 . The Earth's crust formed a single, immense mass. Source: Gicovate (1944)

\section{3 - Final Remarks}

After analyzing the five textbooks of this work, we finally found that none of the authors except Gicovate (1944) cited the Continental Drift theory. Even when Wegener is mentioned, Gicovate (1942) makes no connection between the theory of Continent Drift and the uplift of earthly relief, which would give rise to mountains. Unanimously, all of them also wrote about wrinkling or cooling the crust as causes for elevations or deformations on the earth's surface.

However, technological and scientific progress throughout the 20th century has led to new discoveries that have revolutionized Geosciences. Currently, no Geography textbook presents the wrinkling or slow cooling of the lithosphere as causes for the origin of the folds and mountains.

The Continental Drift theory it is still mentioned in current textbooks, although "it is now accepted that the earth's crust consists of about a dozen superficial lithospheric plates delimited by a web of large faults, deep oceanic pits and extensive submarine mountain ridges" (Tassinari \& Dias Neto 2009, page 78-79). 
These ideas constitute the concept of global tectonics, something that did not exist until a little beyond the first half of the twentieth century, both in academics and in education.

Such discoveries were essential to reach this knowledge and popularize its themes in school and textbooks.

\section{Conclusion}

The textbooks have a defining role of what is taught. Schoolbooks are historical objects that represent a production of a particular generation. They make up the school culture of an era and reflect the degree of scientific advancement and / or the circulation of ideas at the time of its publication. Through the analysis of older textbooks, we can learn more about the curricular program of an era and its contents addressed by the authors (Costa 2012).

After analyzing these works, we observed that these authors considered the wrinkling of the crust as the main cause related to the formation of mountains and folds and faults.

In general, this wrinkling would be associated with a decrease in the temperature of the planet, in other words, its slow cooling, which would cause a decrease in terrestrial volume, and, consequently, the genesis of folds and faults (fractures) along the geological time.

Of the five books reviewed, only one book mentions Alfred Wegener's theory of continental drift. Facing this fact, we can infer two hypotheses: the first is that such a theory, not being accepted and nor proven by the scientific community of its time, was not contemplated in Brazilian textbooks. The second hypothesis could be related to the official curriculum adopted by the government in the past for Geography textbooks.

Perhaps the Continental Drift was not part of the official curriculum proposed by the Brazilian government in textbooks and, therefore, it would not be a surprise if we did not find this subject in the books analyzed. It is important to remember that until the present article, we have no certainty about these subjects, but we will advance to the reader that this investigation will be done in the future, in a master's thesis. Therefore, after analyzing these ancient books of Geography; we can not condemn its authors for ideas now outdated, with little scientific rigor or even for not citing the Continental Drift. Such authors worked on their books according to the tools and theories of their time. Moreover, for each period, a different kind of book was used. As scientific and editorial advances occur, these books change and adapt to new realities.

The awareness of the dynamism of Science as part of human construction and the process of validation and sedimentation of scientific theories and models, influenced by the worldview of a certain society and by the scientific advances, is of fundamental importance for the formation of the student throughout his school life. In this sense, the present article, and more comprehensively, the ongoing master's research, may foster interesting reflections for the teaching of Earth Sciences.

\section{Acknowledgement}

To the Graduate Program of Teaching and History of Earth Sciences, and the Geosciences Institute of Unicamp, for the opportunity to publish our article.

\section{References}

Azevedo A. 1961. Geografia Geral. Primeira série ginasial. 196 ed. São Paulo: Cia. Editora Nacional.

Branco S.M., Branco F. C. 1992. A deriva dos continentes. 1. ed. São Paulo: Moderna. v. 1. 78p.

Costa L.B. 2012. Os manuais escolares como documentos históricos. URL: www.geociencias.ufpb.br/posgrad/ sernne/artigo39.pdf

Ferreira G.M.L. 2013. Atlas geográfico: espaço mundial. Visualização cartográfica: Marcello Martinelli. 4 ed. São Paulo: Moderna.

Gicovate M. 1944. Geografia Geral. 1 série. São Paulo: Edições Melhoramentos.

Holmes A. 1952. Geología física. [Principles of physical Geology]. Trad. Rafael Candel Vila \& Joaquina Comas de Candel. Ed. Omega S.A.

Lenz L.G. 1942. Geografia. 1 série. 6 ed. São Paulo: Livraria Acadêmica; Saraiva \& Cia.

Lima Filho F.G. 1953. Noções de Geografia Geral. Primeira série curso ginasial. São Paulo: Cia. Editora $\mathrm{Na}-$ cional.

Lima A.G. 1933. Geografia secundária. 1 série. Porto Alegre: Ed. Globo.

Suguio K, Suzuki U. 2003. A evolução geológica da Terra e a fragilidade da vida. 1 ed. São Paulo: Ed. Blücher.

Tassinari C.C.G., Dias Neto C.M. 2009. Tectônica global. In: Teixeira W., Fairchild T.R., Toledo M.C.M., Taioli F. orgs. 2009. Decifrando a Terra. 2. ed. São Paulo: Cia. Editora Nacional/IBEP. v.1. p.78-107.

Vesentini J.W. 2008. Para uma geografia crítica na escola. São Paulo: Ed. do autor, URL: www.geocritica.com.br/ Arquivos\%20PDF/LIVRO01.pdf.

\begin{tabular}{c|c|c|c|c|c}
\hline (C) Terrae Didat. & Campinas, SP & v.14 & n.4 & p. 349-354 & out./dez. 2018 \\
\hline
\end{tabular}

